\title{
(-) castrabar \\ Intradural lumbar disc herniation detected by 3D CISS MRI
}

\author{
Laurence Crivelli, Vincent Dunet
}

Department of Diagnostic and Interventional Radiology, Lausanne University Hospital, Lausanne, Switzerland

\section{Correspondence to} Laurence Crivelli, laurence.crivelli@chuv.ch

Accepted 28 November 2017

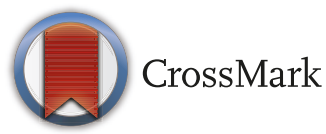

To cite: Crivelli L, Dunet V. BMJ Case Rep Published Online First: [please include Day Month Year]. doi:10.1136/bcr-2017221728

\section{SUMMARY}

A 73-year-old man who presented with right lumbosciatic pain underwent a neurosurgical operation for a voluminous $\mathrm{L} 2-\mathrm{L} 3$ disc herniation, seen on conventional MRI images. No disc herniation was identified in the epidural space during the surgery. Just after the operation, the patient started to present pain in the left $\mathrm{L} 3$ territory and was not able to walk any more. A second MRI including three-dimensional (3D) highresolution constructive interference in steady state (CISS) sequence showed that the voluminous $\mathrm{L} 2-\mathrm{L} 3$ disc split the posterior longitudinal ligament and the anterior dura mater, extended intradurally and compressed the cauda equina to the right. The patient underwent a second surgery, which permitted to cure the symptoms. 3D highresolution CISS should be considered to accurately depict intradural disc herniation in order to optimally guide the surgical approach.

\section{BACKGROUND}

Disc herniation, defined by the protrusion or extrusion of an intervertebral disc outside the discal space, is common and easy to diagnose on MRI or CT scan. More challenging to detect is the intradural disc herniation (IDH), an intervertebral disc nucleus pulposus displacement into the dural sac, ${ }^{1}$ which can change the surgical approach when needed. We present here a case of IDH, which was only accurately depicted by high-resolution MRI. It is very representative of the difficulty to make the diagnosis and illustrates the added value of high-resolution MRI when an atypical disc herniation is suspected.

\section{CASE PRESENTATION}

A 73-year-old patient, known for a previous laminoplasty at L2-L3 and L3-L4, presented with right lumbar radiculopathy with no neurological deficit. A prior conventional MRI described a large L2-L3 left paramedian disc herniation. As no treatment succeeded to relieve the symptoms, surgery was indicated. During the operation, no hernia was found in the epidural space despite an extensive search, and the surgery was interrupted. Soon after, the patient complained of severe left leg pain with inability to walk any more.

\section{INVESTIGATIONS}

A second lumbar spine MRI including a T2-weighted three-dimensional (3D) high-resolution (voxel size $0.5 \times 0.5 \times 0.5 \mathrm{~mm})$ constructive interference in steady state (CISS) sequence was performed. It confirmed the persistence of a left L2-L3 disc herniation. In addition, 3D high-resolution CISS sequence accurately showed that the L2-L3 large paramedian disc extrusion split the posterior longitudinal ligament (PLL; figure 1 line $\mathrm{A}$ on coronal plane) and the anterior dura mater (figure 1 line $\mathrm{B}$ on sagittal plane). It entered into the thecal sac and squeezed the cauda equina (figure 1 line $\mathrm{C}$ on axial plane).

\section{TREATMENT}

Facing the severity of the symptoms and these new MRI findings, a second surgery was planned. After posterior durotomy, nerve roots were gently dissected, and the IDH was progressively extracted. The anterior dura mater breach was then sutured with two no 5 Prolene seams, and nerve roots reduced into the thecal sac. The posterior dura mater was finally sutured and secured with a muscular patch.

\section{OUTCOME AND FOLLOW-UP}

No complication occurred during the operation, and the patient fully recovered within 24 hours without any sequela.

\section{DISCUSSION}

IDHs have an incidence of about $0.30 \%$ of all disc herniations and occur more frequently in the lumbar region. ${ }^{23}$ They can be considered as a complication of intervertebral disc hernias with a perforation of the PLL and the dura mater, ${ }^{1}$ but their aetiopathology remains unclear. Some conditions are described as facilitating factors ${ }^{1-5}:$ (1) adhesions between the annulus fibrosus, the PLL and the dura mater-congenital or acquired, for example, postsurgery, (2) congenital narrowing of the spinal canal with less epidural space or (3) congenital or iatrogenic fineness of the dura. Although cauda equina syndrome has been slightly more reported with IDH at the lumbar level, ${ }^{35}$ the symptoms are not specific and do not help discriminate between an extradural hernia and an IDH. ${ }^{5}$

The best imaging modality for IDH detection is MRI. ${ }^{3}$ A classical image of disc herniation is a mass originating from an intervertebral disc with a hyposignal on T1-weighted and T2-weighted imaging. In association, IDH should be suspected when there is an interruption of the PLL, visible on sagittal view-as in our case. A typical hawk-beak appearance on T2 axial view, that is, a triangular 

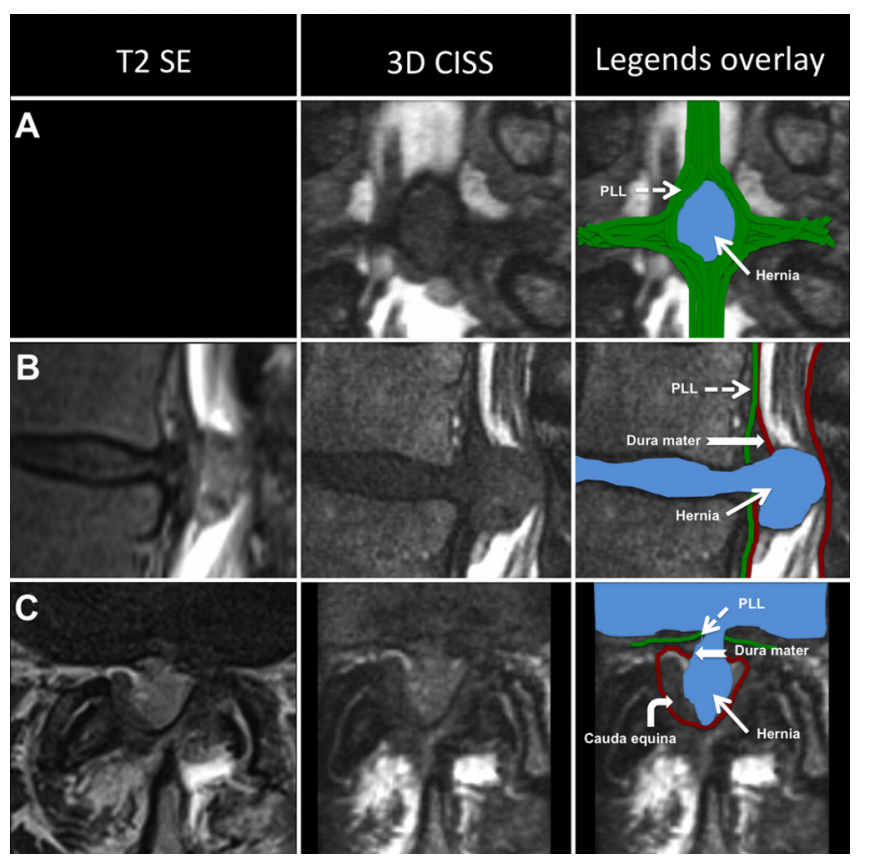

Figure 1 Intradural disc herniation and anatomical relations on 2D T2 spin-echo and 3D CISS sequences. Compared with standard 2D T2 spin-echo (first column), 3D high-resolution CISS MRI (second column) demonstrated that the L2-L3 disc herniation split the PLL (line A on coronal plane) and the anterior dura mater (line B on sagittal plane). The large paramedian left-sided disc extrusion entered into the thecal sac (line $C$ on axial plane). It impinged on the left $L 3$ nerve root and compressed the rest of the cauda equina to the right, with a typical 'hawk-beak' appearance (line C on axial plane). CISS, constructive interference in steady state; PLL, posterior longitudinal ligament; SE, spin-echo; 3D, three-dimensional; 2D, two-dimensional.

image of the disc compressed laterally by the cartilaginous edges of the annulus fibrosus, has also been reported in IDH. ${ }^{23}$ When contrast media is used, which has not been done in our case, a ring enhancement of the herniated portion can be seen, caused by granulation tissue. ${ }^{1-5}$ While $3 \mathrm{D}$ CISS sequence performance is similar to standard T2-weighted images for the depiction of extradural lumbar disc herniation, ${ }^{6}$ the use of 3D high-resolution CISS sequence in IDH has not been reported yet. However, several studies have demonstrated the potential of $3 \mathrm{D}$ high-resolution CISS to assess other intradural diseases such as redundant nerve root syndrome of the cauda equina ${ }^{7}$ or thoracic anterior spinal cord adhesion syndrome. ${ }^{8}$ By allowing the detection of subtle rupture of the PLL and dural defect, ${ }^{9}$ 3D high-resolution CISS should be considered also in case of suspicious IDH.

As IDH is a rare pathology and its detection is difficult with conventional MRI examination, most of the cases are discovered intraoperatively or, as in our case, suspected when there is a discrepancy between the radiological images and the surgical findings. While IDH can be removed extradurally when the disc fragment extends from the epidural space into the intradural space, intradural fragments can be removed only by durotomy. ${ }^{10}$ Moreover, IDH prognosis is related to the duration of the symptoms, their severity and the easiness-no or multiple previous operation at the same site-and efficiency-complete or partial removal of the disc fragment-of the surgery. ${ }^{13}$ Improvement of presurgery MRI analysis is consequently of paramount importance, as it can completely change the operative plan ${ }^{2}$ and patient's prognosis.

To conclude, 3D high-resolution CISS MRI may accurately depict IDH. This sequence should be considered when IDH is suspected in order to optimally guide the surgical approach. Both radiologists and neurosurgeons should be aware of the potential of 3D high-resolution CISS sequence in such tricky cases.

\section{Learning points}

- Intradural disc herniation (IDH) is a rare pathology, described as an intervertebral disc nucleus pulposus displacement into the dural sac.

- IDH should be suspected on conventional MRI when there is an interruption of the posterior longitudinal ligament on sagittal view, a hawk-beak sign on axial view and a ring enhancement of the discal fragment when contrast media is used.

- Three-dimensional high-resolution constructive interference in steady state sequence should be considered when IDH is suspected on conventional MRI to improve surgery planning.

Contributors Both authors significantly contributed to this work, read and approved the final version, did a literature review about the subject and wrote the case report. LC wrote about the disease part in the first draft. VD wrote about the MRI technical part. Both authors commented and added corrections to the entire case report in the following drafts and accepted the final version.

Competing interests None declared.

\section{Patient consent Obtained.}

Provenance and peer review Not commissioned; externally peer reviewed.

Open Access This is an Open Access article distributed in accordance with the Creative Commons Attribution Non Commercial (CC BY-NC 4.0) license, which permits others to distribute, remix, adapt, build upon this work non-commercially, and license their derivative works on different terms, provided the original work is properly cited and the use is non-commercial. See: http://creativecommons.org/ licenses/by-nc/4.0/

(C) BMJ Publishing Group Ltd (unless otherwise stated in the text of the article) 2017. All rights reserved. No commercial use is permitted unless otherwise expressly granted.

\section{REFERENCES}

1 D'Andrea G, Trillò G, Roperto R, et al. Intradural lumbar disc herniations: the role of MRI in preoperative diagnosis and review of the literature. Neurosurg Rev 2004;27:75-80.

2 Choi JY, Lee WS, Sung KH. Intradural lumbar disc herniation-is it predictable preoperatively? A report of two cases. Spine J 2007;7:111-7.

3 Ducati LG, Silva MV, Brandão MM, et al. Intradural lumbar disc herniation: report of five cases with literature review. Eur Spine J 2013;22(Suppl 3):404-8.

4 Hida K, Iwasaki Y, Abe $\mathrm{H}$, et al. Magnetic resonance imaging of intradural lumbar disc herniation. J Clin Neurosci 1999;6:345-7.

5 Kobayashi K, Imagama S, Matsubara Y, et al. Intradural disc herniation: radiographic findings and surgical results with a literature review. Clin Neurol Neurosurg 2014;125:47-51

6 Aydin $\mathrm{H}$, Kizilgoz V, Hekimoglu B. Compared with the conventional mr imaging, do the constructive interference steady state sequence and diffusion weighted imaging aid in the diagnosis of lumbar disc hernias? Eurasian J Med 2011;43:152-61.

7 Nayman A, Ozbek S. Redundant nerve root syndrome of the cauda equina: the benefits of 3D CISS MRI sequence. Spine J 2015;15:e31.

8 Taylor TR, Dineen R, White $B$, et al. The thoracic anterior spinal cord adhesion syndrome. Br J Radiol 2012;85:e123-9.

9 Sakoda A, Yamashita KI, Hayashida M, et al. A case of superficial siderosis ameliorated after closure of dural deficit detected by MRI-CISS (constructive interference in steady state) imaging. Rinsho Shinkeigaku 2017;57:180-3.

10 Ozer E, Yurtsever C, Yücesoy K, et al. Lumbar intraradicular disc herniation: report of a rare and preoperatively unpredictable case and review of the literature. Spine $J$ 2007;7:106-10. 
Copyright 2017 BMJ Publishing Group. All rights reserved. For permission to reuse any of this content visit http://group.bmj.com/group/rights-licensing/permissions.

BMJ Case Report Fellows may re-use this article for personal use and teaching without any further permission.

Become a Fellow of BMJ Case Reports today and you can:

- Submit as many cases as you like

- Enjoy fast sympathetic peer review and rapid publication of accepted articles

- Access all the published articles

- Re-use any of the published material for personal use and teaching without further permission

For information on Institutional Fellowships contact consortiasales@bmjgroup.com

Visit casereports.bmj.com for more articles like this and to become a Fellow 